this case an interaction with tubulin dimer is suspected as well: here again there is cross-reaction with another microtubuleassociated protein, MAP I ${ }^{9}$. Brain spectrin and ankyrin may indeed be the first examples of membrane-associated microtubule-binding proteins. An indication of an interaction between spectrin and intermediate filaments has come from evidence that when anti-spectrin antibodies are microinjected into cultured cells, not only is spectrin precipitated, but the organization of the intermediate filaments is disrupted ${ }^{10}$.

Support for the idea that spectrin is somehow involved in maintaining the physical state of membranes comes from the elegant immunofluorescence studies of Koenig and Repasky ${ }^{11}$, who show that isolated axons are enriched in spectrin where they are not enclosed by a myelin sheath, that is at the nodes of Ranvier and the synapses. It therefore seems that spectrin is involved in the generation and maintenance of plasma membrane domains. However, this cannot be the whole story since the same group has discovered an association between spectrin, as well as calmodulin and $\mathrm{F}$ actin, and the rapidly moving axonal particles (motile varicosities), which are seen in axons regenerating in vitro ${ }^{12}$. This suggests that the role of spectrin also encompasses the linkage of organelle membranes with cytoskeletal elements. Aunis and Perin ${ }^{13}$ have added a further twist by suggesting the implication of spectrin in chromaffin granule exocytosis. If spectrin is indeed involved in exocytosis then its concentration at the synapse could be taken to imply a role in neurotransmission. A further recent conjecture is that the cleavage of spectrin on post-synaptic membranes, triggered by depolarization-induced events, may be involved in memory storage ${ }^{14}$.

So in answer to the question of the cellular functions of spectrin, a general role is now discernible. Spectrin seems frequently to link cytoskeletal elements to plasma or other (for example exocytic) membranes, or to regulate that linkage. Cells may use the linkage in a variety of ways, including the generation and stabilization of plama membrane domains, the facilitation of intracellular transport (leading in certain cases to exocytosis) and the regulation of the activities of transmembrane proteins. Watch this space.

1. Baines, A.J. Nature News and Views 301, 377 (1983).

2. David, J. \& Bennett, V. J. biol. Chem. 258,7757 (1983).

3. Nelson et al. J. Cell Biol. 97,1271 (1983).

4. Speicher et al. J. biol. Chem. 258, 14931 (1983).

5. Ishikawa, M. J. Biochem. 94, 1209 (1984).

6. Carlier, M.F. et al. Biochimie 66, 305 (1984).

7. David, J. \& Bennett, V. J. biol. Chem. 257, 5816 (1982).

7. David, J. \& Bennett, V. J. biol. Chem. 257, 5816 (1982)

9. Bennett, V. \& David, J. Proc natn. Acad. Sci. 78, 7550 (1981).

10. Mangeat, P. \& Burridge, K. J. Cell Biol. 98, 1363 (1984).

11. Koenig, E. \& Repasky, E. J. Neurosci. (in the press).

12. Koenig, E. et al. J. Neurosci. (in the press).

13. Aunis, D. \& Perin, D. J. Neurochem. 42, 1558 (1984).

14. Lynch, G. \& Baudry, M. Science 224, 1057 (1984).

A.J. Baines is in the Department of Cell Biology and Anatomy, Johns Hopkins University Medical School, Baltimore, Maryland, 21205, USA.

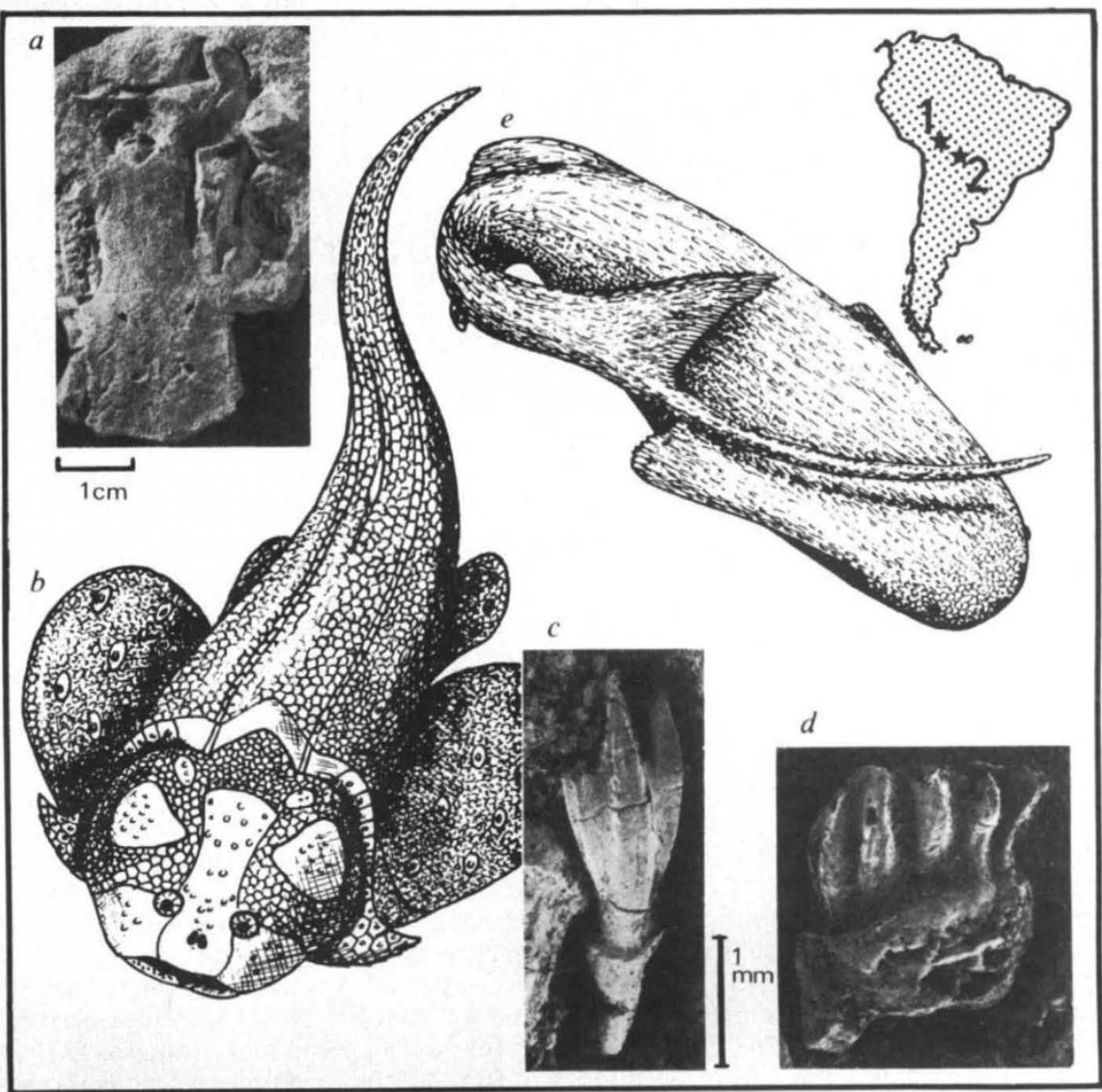

\title{
Devonian vertebrates from South America
}

DEVONIAN vertebrates have been recorded from every continent except South America, where only a few fossils have been tentatively referred to this group (Janvier, P. Program. intern. Correlat. geol., La Paz 44 1; 1978). The most convincing of these is a footprint of an amphibian, from the Devonian of Brazil. Lower and Middle Devonian sites of western and central Bolivia have now yielded scales of agnathans, spines and scales of acanthodians and sharks, and a skull and plates of a placoderm.

The figure illustrates two of the Devonian fishes we have excavated. The Middle Devonian Sicasica Formation, which extends south of La Paz on the Altiplano (site 1 on the map) yielded a well preserved braincase and the jaws of a rhenanid (a), a rare group of placoderms (armoured fishes) known from the Devonian of Europe and North America. There are close similarities between these fossils and a complete rhenanid, Gemuendina stuerzii (b) excavated from the Lower Devonian of Hunsrück, FRG. South-east of the Altiplano in the Chuquisaca district (site 2 on the map), the Lower Devonian Catavi Formation crops out along the Rio Grande at Seripona. There, a rich bone-bed has yielded remains of acanthodians, sharks and thelodonts, a group of jawless vertebrates. Two types of thelodont scales $(c, d)$ from this locality may have belonged to a form resembling Turinia (e), known from the Lower Devonian of Scotland. The scales also resemble those of a thelodont recently decribed from the Devonian of Australia, Australolepis seddoni. Similarly, peculiar shark spines from the locality recall those of Antarctilamna, from the Middle Devonian of Antarctica and Australia.

Moreover, large acanthodian spines from Seripona, as well as from several other Lower Devonian localities in Bolivia, display the same superficial ornamentation, with alternating broad and narrow ridges without nodes, as the spines of Sinacanthus, a large climatiid acanthodian from the Middle Devonian of south China.

Any large-scale biogeographic conclusions would be premature. But at a time when the early history of the Pacific is being vigorously discussed by geophysicists and palaeobiogeographers (Nur, A. \& BenAvraham, Z. in Vicariance Biogeography, a Critique, 341 (Columbia University Press, 1983), the Devonian fishes of South America should provide a valuble tool for estimating Palaeozoic trans-Pacific relationships, particularly since most of them lived very near to the continental shore.

Daniel Goujet and Philippe Janvier, Centre National pour la Recherche Scientifique Institut de Paléontologie, 8 rue Buffon, 75005 Paris, France; $M$. Suarez-Riglos, Centro de Tecnologia Petrolera, Yacimientos Petroliferos Fiscales Bolivianos, Casilla 7272, SantaCruz, Bolivia. 